\title{
Cultural Battles: Margaret Thatcher, the Greater London Council and the British Community Arts Movement
}

Une bataille culturelle: Margaret Thatcher, le Conseil du Grand Londres et le mouvement britannique des Community Arts

Mathilde Bertrand

\section{(2) OpenEdition}

\section{Journals}

Electronic version

URL: https://journals.openedition.org/rfcb/8435

DOI: $10.4000 / \mathrm{rfcb} .8435$

ISSN: 2429-4373

Publisher

CRECIB - Centre de recherche et d'études en civilisation britannique

Electronic reference

Mathilde Bertrand, "Cultural Battles: Margaret Thatcher, the Greater London Council and the British Community Arts Movement", Revue Française de Civilisation Britannique [Online], XXVI-3 | 2021, Online since 14 December 2021, connection on 05 January 2022. URL: http://journals.openedition.org/rfcb/ 8435 ; DOI: https://doi.org/10.4000/rfcb.8435

This text was automatically generated on 5 January 2022.

\section{c) (i) $(9)$}

Revue française de civilisation britannique est mis à disposition selon les termes de la licence Creative Commons Attribution - Pas d'Utilisation Commerciale - Pas de Modification 4.0 International. 


\section{Cultural Battles: Margaret Thatcher, the Greater London Council and the British Community Arts Movement}

Une bataille culturelle: Margaret Thatcher, le Conseil du Grand Londres et le mouvement britannique des Community Arts

Mathilde Bertrand

\section{Introduction}

1 The community arts movement, which developed from the late 1960s through the 1980s, was one of the many fires sparked in the United Kingdom on issues concerning culture and power. It belonged to a broader left-wing movement inspired by the New Left, structured around concerns for democracy, popular cultures, pluralism, collective action and an understanding of the cultural field as political. ${ }^{1}$ Paving the way to for critical debates on legitimate and illegitimate culture, access to the arts, and the competing objectives of democratising culture or enabling cultural democracy, the intellectual milieu of the Centre for Contemporary Cultural Studies, founded in 1964, produced a critique addressing the structuration of processes of cultural hegemony and power relations within the sphere of culture. It also enabled a revaluation of popular cultures, hitherto considered unworthy of study. In the same period, the Wilson government harnessed culture as an instrument in the modernisation of society - and of the Labour Party's image. Jenny Lee's Ministry for the Arts oriented the Arts Council of Great Britain away from its then established rationale of supporting and "spreading" elite culture. ${ }^{2}$ In a period regarded as the "golden age" of the Arts Council, its action associated increased access to artistic practice, support for avant-garde art forms and a redefinition of popular culture away from reductive assignations to the commercial sphere. ${ }^{3}$

2 In this context, the community arts movement contributed to producing a radical critique of the cultural Establishment and bourgeois aesthetic canons, while agitating 
for the equal recognition of popular artistic practices and forms of cultural expression. The perceived elitism of a largely metropolitan cultural industry was criticised for fostering conservative, patronising conceptions of culture and catering for middle-class audiences and exhibition-goers, while sustaining the idea that the art world was politically neutral. Against these definitions of culture, the hundreds of local projects which appeared across the country offering arts activities open to all contributed to objectives of social, cultural and political change by enabling access to artistic production and providing opportunities for engaging with artistic practices. ${ }^{4}$ Inspired by Paolo Freire's Pedagogy of the Oppressed and Augusto Boal's Theatre of the Oppressed, community arts practices were nurtured by the political ferment of countercultural activities and intellectual debates in the 1960s. The term "community arts" appeared at the end of the decade in association with artistic initiatives developed outside of established institutions, by young artists determined to find an alternative role and inspirations for their art, at the service of the needs and aspirations of local communities. ${ }^{6}$ Influenced by the political agitation in French and British art schools, and critical of an art education they considered too remote from social issues and narrowly concerned with studio practice, they defended a conception of culture and the arts which was not elitist, but plural and driven by objectives of social change and cultural democracy.

3 The community arts movement opposed the cultural Establishment as much as it contested the encroachment of market forces on the cultural field and the commodification of culture. It shared such positions with the British cultural underground, and yet community arts cannot be said to have been underground, in the sense specified by the OED as that which "pertain[s] to a subculture which seeks to provide radical alternatives to the socially accepted or established mode". ${ }^{7}$ While community arts did seek "to provide radical alternatives to the socially accepted mode", it did not constitute, or did not consider itself to be part of, a "subculture", understood as a system of values and attitudes, characterized by a set of signifying practices inscribed in styles, rituals, tastes, in stark opposition to dominant culture. ${ }^{8}$ Community arts sought to challenge the mainstream, "to change the whole cultural agenda of this country, [...] explor[e] the possibility of finding different ways for art to function in society"9 and radically redefine culture towards much more inclusive, diverse and popular forms of expression and meanings.

4 The focus of this article will be on the trajectory of the movement in the 1980s, with incursions into the 1970s, a period of structuration and significant development, when community arts managed to attract some institutional recognition and both private and public funding. To examine the evolution of community arts under successive Conservative governments is to shed some light on the cultural battles played out in the 1980s, which pitted radically opposed views on the social role of culture and the arts. In the course of that decade, community arts organisations across the country were undermined by budget cuts, while the radically oppositional impetus of the movement was neutralised in the new political and ideological climate of Thatcherism. A key player in these cultural battles, the Greater London Council chaired by Ken Livingstone (Labour) from 1981 to 1986 became a champion for community arts, giving them a full role within its Arts and Recreation Committee. The Conservative government's abolition of the GLC and the other Metropolitan County Councils in 1986 
was its response to the political challenges that these powerful Labour administrations raised, affecting the community arts movement adversely.

\section{Community Arts in the 1970s}

5 Community arts organisations appeared in the UK from the late 1960s as isolated initiatives rooted in an alternative collective ethos, offering politicised arts activities ranging from street theatre, mural painting, silk-printing, crafts, creative writing, music, photography or video to marginalised and underprivileged audiences. Community artists saw their role as making artistic experience, resources and skills available to people in their local communities, in areas where little or no provision was made to facilitate access to and participation in the arts. The community arts movement raised the central question of the role of arts and artists in society, against dominant conceptions of art which assimilate it to high culture and to the work of individual artists legitimised by established institutions and experts. Underpinning these activities was the radical claim that access to the means of cultural expression is a right, irrespective of people's social background, education or expertise. ${ }^{10} \mathrm{~A}$ central tenet was that participation and the possibility of co-authorship in making art rendered possible processes of individual and collective empowerment:

Three main threads drove the community arts initiative. First, there was a passion for creating new and liberating forms of expression. Second, there was a move, by mainly fine artists, out of the institutionalized galleries and onto the street. Third, there was an emergence of a new kind of political activist, one who believed that creativity was an essential tool in any kind of radical struggle. ${ }^{11}$

Independently from one another, community arts organisations began to apply for grants from the Arts Council of Great Britain, staking their claims on public money for the art projects they were developing on the ground. Adopting a radical approach, they contested the hierarchies of the art world, and what they perceived as the elitism of the Arts Council's patronage of the arts, reflected in funding choices which privileged a minority of established cultural institutions rather than new cultural initiatives concerning the many. The response of the Arts Council was to set up specific committees to process the growing number of demands from these organisations of a new kind: ${ }^{12}$

These activities [...] did not fall into the traditional arts slots and so a suitable pigeon-hole had to be found. In 1973, the Arts Council decided to set up a working party to look at how this new area could be made to fit into their overall work. ${ }^{13}$

The "Community Arts Working Party", chaired by Pr. Harold Baldry, published a report in 1974 which advised the Arts Council to commit to funding community arts and to setting up a dedicated committee for an experimental period of two years (1975-77). The report is regarded as having informed the subsequent relationship between the Council and community arts movement. ${ }^{14}$ The report cautiously warned that community arts represented a challenge to the Council's perceived defence of legitimate culture, and that community artists opposed what they regarded as established bourgeois culture:

Many community artists are in revolt against the accepted forms [...] and the majority are not primarily concerned with improving knowledge or understanding of our heritage or traditions, or with practice of the arts leading to a product that can be judged by normally accepted standards. ${ }^{15}$ 

does seem to come within the spirit" of Clause $3 \mathrm{~b}$ of its Royal Charter of Incorporation (1967) ("to increase the accessibility of the arts to the public throughout Great Britain"). ${ }^{16}$ Importantly, the report stressed that "the Council should not only accept involvement but should be seen to be involved." ${ }^{17}$ In other words, it was considered positive and safe for Arts Council to commit to funding community art activities, ${ }^{18}$ and this proved useful in helping it democratise access to the arts, while containing its radical edge by maintaining funding low:

Funding for community arts at this stage took the form of small amounts of money which were administered by sub-committees, keeping this potentially challenging voice separate from the mainstream, united in its opposition, and partially satisfied. The need to find a coherent definition was never taken on board, because some people were too busy fighting for funding, some were too busy fighting for their ideas to be recognized, and some were even busier doing both." ${ }^{19}$

The continuous search for short-term funding, from limited sources, kept community arts organizations in a tension between ensuring their independence and securing economic viability. The Association of Community Artists, created in 1974 to coordinate a growing number of heterogeneous community arts projects, took the pragmatic path of actively campaigning for more funding from both public and private sources..$^{20} \mathrm{At}$ the time, few within the ACA saw the importance of reaching a conceptual agreement and setting a common political agenda that could constitute a rallying platform for a radically democratic concept of culture and the arts in the UK. To community artist Owen Kelly, this constituted a missed opportunity, on the part of the movement, to fundamentally challenge what he saw as the Arts Council's bourgeois conception of the arts and arts provision and propose a radical, unified political base for a complete restructuration of funding policies for the arts as well as an alternative, democratic, conception of culture. ${ }^{21}$

10 The relationship between the community arts movement and the Arts Council in the 1970s highlights struggles over definitions of culture, cultural legitimacy, participation, access and co-authorship in cultural production. The election of a Conservative government opened an altogether different cultural battle where community arts were dismissed as political agitation and the hegemony of a conservative conception of culture - adapted to then emerging neoliberal practices - was reasserted.

\section{A clash of values: community arts under Thatcherism}

11 The Conservative Party won the elections in May 1979 with a political programme committed to cutting public expenditure, lowering taxes and reducing the power of trade unions. The realisation of these aims was seen as a condition for an enterprise culture to flourish. The change was to be effected by privatising a number of national companies, thus providing individuals and companies with opportunities to invest in sectors which had remained in the public domain in the broad post-war consensus. Culture and the arts were to adapt to the new orientations, and become used to being considered as a sector with economic potential.

In keeping with its general economic agenda, the Conservative government submitted the cultural sector to a regime of cuts and a growing reliance on private funding sources. This move was also in line with a broadly-held view especially within the 
Conservative Party, that the government should not interfere in the cultural sector, but rather keep away from the risk of instrumentalising and politicising it. ${ }^{22}$ The Conservative government was responsible for introducing private and commercial sponsorship in the cultural sector, thanks to tax incentives and the promise of economic returns. This was a central proposal in the 1979 Conservative Party Manifesto, which considered that "lightening the burden of tax should in time enable the private sponsor to flourish again" (Conservative Party, 1979). The Prime Minister herself did not hide the fact that she was no supporter of public subsidies for the arts, invoking the deeply rooted Conservative argument that the State should not meddle with the creativity of artists: ${ }^{23}$

I was not convinced that the state should play Maecenas. Artistic talent - let alone artistic genius - is unplanned, unpredictable, eccentrically individual. Regimented, subsidized, owned and determined by the state, it withers. [...] I wanted to see the private sector raising more money and bringing business acumen and efficiency to bear on the administration of cultural institutions. I wanted to encourage private individuals to give by covenant, not the state to take through taxes. ${ }^{24}$

13 Early into the new administration, it became clear that times were changing. In 1980 Norman St John-Stevas, the Minister for Education and the Arts, announced that "the arts world must come to terms with the fact that Government policy in general has decisively tilted away from the expansion of the public to the private sector." ${ }^{25}$ Business sponsorship as well as marketing and commercially-oriented activities were to be developed in order to make up for the shortfall. ${ }^{26}$ From this moment onwards, the Association for Business Sponsorship of the Arts, active from 1976, gained a prominent role in the shift towards the generalisation of private streams in arts funding policy. Its director, Luke Rittner, was appointed Secretary-General of the Arts Council in 1983. By the end of the 1980s, the idea that private sponsorship of the arts was inevitable had become widely accepted. ${ }^{27}$

The political orientations of the new Conservative government for the cultural sector drastically transformed the operation, scope, and working practices of the Arts Council. It challenged the established "arm's length" principle which had hitherto protected it from government control and given it a semi-autonomous capacity to allocate funding according to the decisions of its different specialist (unelected) committees. Curbing the power of the Arts Council followed a twofold process consisting in "apply[ing] financial pressure, in the name of reducing government spending, and us[ing] the power of appointment to ensure that institutions voluntarily bent to the government's will". ${ }^{28}$ This was done in the course of Margaret Thatcher's first mandate. Sir William Rees-Mogg, a wellknown politically and culturally conservative figure, was appointed Chairman of the ACGB in 1982, while the Arts Council's budget was suddenly cut by one million pounds in $1980 .{ }^{29}$ For the first time in its history, the Council was forced to reduce its recipients' allocated funds or withdraw them completely, as was the case for forty-one small theatre and community arts companies. ${ }^{30}$ In the same year, the Arts Council, although recognizing the value of community arts projects, decided to put an end to the activities of the Community Arts Committee and devolve this function to the Regional Arts Associations. "B1 "By 1982, the Arts Council had almost entirely ceased funding community arts directly". ${ }^{32}$ This had the effect of placing responsibility for cultural provision with local authorities and the Regional Arts Associations, with the risk of regional disparities and fluctuating commitment to the sector depending on priorities 
determined locally. It deprived the community arts movement from a national recognition and framework and played a role in its future fragmentation.

The community arts movement could not have been more ideologically opposed to the new order and vision that Thatcher wanted to see triumph, a combination of neoliberal economic principles, conservative values and capitalist individualism. At a time when the movement was being weakened by cuts, was becoming increasingly professionalized and fragmented, some of the more radical participants in the movement advocated for community arts organisations to rally behind a clear definition of aims, values and principles. In 1984, the Shelton Trust, set up in 1979 by the Association of Community Artists, organised a campaign designed to promote its definition of the concept of cultural democracy as both an aim and a working method for community arts. ${ }^{33}$ Firmly rooted on the left, the more radical voices which inspired the Shelton Trust fought for a definition of cultural democracy which held that equal access to the means of cultural production and the recognition of the diversity of forms of cultural expression were part and parcel of an ideological revolution designed to overthrow capitalism..$^{34}$ At a national community arts conference in 1986, Cultural Democracy: The Manifesto was submitted to members. After two defeats in the General Elections and with internal divisions, the Labour Party was in a state of disarray. To the authors of the manifesto, if socialism was to offer a real alternative to Thatcherism, it had to engage fully with popular culture and make it a base for the development of democratic practices across all sectors:

We believe that socialists must develop a coherent view of culture. We cannot afford to respond to dominant right-wing individualism by arguing for a bit more of this and a bit less of that. Instead, we must produce a positive understanding and practice which arise from a different, a socialist view of the role that culture plays under capitalism, and the role it plays as a vital part of a democratic socialism. ${ }^{35}$

To posit cultural democracy as an objective and a principle of practice stemmed from a wider critique within the New Left of the 1960s of dominant hierarchical culture, produced, supported and controlled by an elite, reproducing in the cultural field patterns of oppression found across social spheres. The manifesto called on left-wing organisations to make cultural democracy a core tenet of all political activism, linking it as it did with anti-capitalism. The concept implied a complete redefinition of what "the arts" meant and of their role in society, as well as embracing principles of democratic participation in the production, distribution and support of the arts:

The ideas that constitute cultural democracy both enable and depend upon direct participation, and take as their aim the building and sustenance of a society in which people are free to come together to produce, distribute and receive the cultures they choose. ${ }^{36}$

17 Ultimately two radically opposed conceptions of culture and of its role were pitted against each other: one which combined deeply conservative values with the pursuit of commercial profit, the other based on popular definitions calling for the advent of a cultural democracy in a socialist society. Judging from the very few passages in her memoirs addressing the question of culture, the Prime Minister was primarily concerned with the prestige and international attractiveness of national institutions, the preservation of national heritage sites, and the economically successful productions of the West End's commercial theatres. She appeared determined to root out what she identified as the cultural legacy of the 1960s countercultural left, which included the community arts movement. Margaret Thatcher considered activities of 
this kind, in receipt of public funding, as experiments of a vocal "arts lobby" pursuing ideological goals and political agendas incompatible with her own elitist, nationalist and neoliberal conception of cultural development. ${ }^{37}$ "The British soul was to be remade, by creating a new myth of economic individualism to replace the old ideas of community and collectivism". ${ }^{38}$ The fact that culture was an ideological battle ground became particularly clear during Ken Livingstone's leadership of the Greater London Council, which during five years created the conditions for its own brand of "municipal socialism", supportive of community arts, to flourish.

\section{The Greater London Council (GLC) and the "campaign for a popular culture"}

In May 1981, as Labour councillors won a majority in the local elections in London, Ken Livingstone became leader of the Greater London Council. Between that date and the abolition of the GLC in April 1986, London became a bastion of opposition to the government's policies, and a unique experiment in the development of a renewed radical socialism. Under Livingstone's leadership, the capital embodied a political and cultural resistance to the neoliberal and conservative ideological turn, what Stuart Hall called "the Great Moving Right Show". ${ }^{39}$ The GLC along with the six Metropolitan County Councils $\mathrm{s}^{40}$ "represented alternative centres of political power to Whitehall, and [were] the least amenable to attempts to curb public spending" ${ }^{41}$ From County Hall, facing the Houses of Parliament, the GLC implemented radical policies which championed women's rights, gay rights, ethnic minorities, working-class people, the young, the disabled and the elderly, while actively addressing issues such as unemployment, nuclear disarmament, Northern Ireland or accessible public transport. Culture and the arts were closely associated to the different campaigns led by the GLC, and given the role of demonstrating the possibility of political alternatives to the new dominant ideology.

The GLC administration set up an Arts and Recreation Committee, chaired by Tony Banks, which worked hand in hand with other committees such as the Industry and Employment Committee, the Women's Committee or the Ethnic Minorities Committee. Its programme of cultural activities included music festivals in public parks, free cultural events on the Southbank and the increased accessibility of venues such as the Royal Festival Hall where an "open foyer" policy was started. Two specific subcommittees were created, one dedicated to Ethnic Arts and the other to Community Arts. "At a time when [the community arts movement] was increasingly becoming depoliticised" at a national level, the GLC recognized the potential of these practices, grounded in collective action and work with local communities. ${ }^{42}$ The Community Arts Sub-committee was committed to supporting grassroots organisations and encouraging access to and participation in their cultural activities, "thereby asserting space for cultural forms of community activism in the city". ${ }^{43}$ It was first chaired by Alan Tomkins (1981-84) and brought together seventeen advisors appointed for their experience in the field and the depth of their connection with local communities and grassroots campaigns. Tomkins made it explicit that community arts were to play a role in "shaping a progressive socialist arts policy" ${ }^{44}$ Therefore, principles developed within the community arts movement in the preceding decade such as encouraging the democratisation of cultural production, defending non-professional artistic practices, ensuring people's 
equal access to artistic practice and appreciation, and championing cultural diversity were adopted by the sub-committee as guidelines for its action. Cultural democracy was recognized as an aim and a principle of practice:

The Community Arts Sub-committee's funding went to support the making of a popular culture [...] It funded cultural activities which are "of the people", which belong to, and are part of ordinary people's lives rather than activities which are "for the people", and which speak to them from outside their own lives and experiences. ${ }^{45}$

Influenced by theoretical perspectives from Cultural Studies and the New Left, the GLC's cultural strategy was grounded on a political understanding of culture as a conflictual site where different ideological meanings, forms and representations circulate, become dominant or are marginalised. Cultural domination which normalized and legitimised bourgeois conventions, norms and hierarchies had to be tackled by policies which enabled the expression of alternative voices and cultural forms. This strategy was spelt out in one of the GLC's reports on the arts: "One of the aims of the GLC's cultural policy was to help change both the hierarchy of legitimacy of cultural forms and the meanings circulating in our society, such as the representations of gender and race" ${ }^{46}$ Under Livingstone's leadership, the GLC became an advocate for these marginalized and silenced voices and cultures. "In its enabling function as a funding agency, the GLC operated a social engineering strategy aimed at endowing certain constituencies with an independent cultural voice" ${ }^{47}$ The Labour-led GLC recognized that, partly because of Thatcher's industrial policy and onslaught on trade unionism, the traditional working-class vote was declining, while new constituencies were emerging, particularly in London:

There was a need to establish links with new groups of voters: black British, Asians, middle-class people working in the public sector, and the small but articulate groups of gays and lesbians. A cultural policy which addressed the interests of those groups became an alternative form of mobilization and communication..$^{48}$

21 The GLC's Arts and Recreation Committee played an active role in events such as the GLC Peace Year in 1983 (on nuclear disarmament), the "Jobs for a Change Festival" in 1985, or gave support to the London Against Racism campaign or the solidarity campaign for the miners' strike (1984). Such events bore the imprint of earlier mass mobilisations, combining politics and the arts such as Rock Against Racism (1977-78) where punk and reggae bands, their fans, as well as graphic designers and photographers, rallied at anti-racist concerts. The GLC drew inspiration from such uses of popular culture and modern forms of artistic expression to address specific political issues in large collective and festive events. Harnessing the creative industries in support of political causes contributed to the construction of the GLC's image as a modern socialist council which worked for young people, ethnic minorities, the unemployed, women or sexual minorities.

The Community Arts Sub-committee more specifically supported organisations which responded to the following issues of practice: an interest in the development of noninstitutionalised art forms and new media activities (in film, video, photography, printing); an attention to distribution networks, ensuring that the works reached their audience; a concern with marginalized groups; the encouragement of skill-sharing and genuine participatory forms of production. Many of the organisations supported by the GLC were collectives and workshops, self-organised and anti-hierarchical structures favouring egalitarian practices. Theatre groups, music centres, mixed community arts 
organisations, poster-printing organisations (such as the See Red Women's Workshop), ${ }^{49}$ independent structures (such as Centreprise, an independent bookshop in Hackney offering a variety of creative and collective activities), were recipients of GLC funding. So were organisations offering activities around film (the Basement in Tower Hamlets) or photography (the Blackfriars settlement, the North Paddington community darkroom, Camerawork in Bethnal Green, the Cockpit Gallery in Holborn). ${ }^{50}$ The GLC was particularly interested in the uses of photography as a mode of expression for young people, the technique being easily taught, relatively inexpensive and interesting to use in youth club projects or local campaigns. Such workshops and organisations provided access to means of expression and representation to ordinary people whose voices and perspectives were seldom heeded:

[The Community Arts Sub-committee] wanted these groups to compete with their commercial counterparts on more equal terms and begin countering the damaging way in which people and groups are represented in the media. [...] The fundamental policy of the sub-committee was to support projects working in contemporary communication media who were developing methods of representing the world and the people who live in it which gave their subjects control over the forms in which they were portrayed, rather than simply squeezing them into the stereotypes and categories used by the dominant cultural media such as television, radio, newspaper and magazines. ${ }^{51}$

In terms of funding, support was given to cultural events and projects in three different forms: for specific projects; as revenue grant for annual running costs and wages; as capital grants for the building or refurbishing of property. The number of applications for projects amounted to thirty-six in 1981-2, for a budget of $£ 71,193$. In 1984-85 this had risen to 189 applications for a total sum of $£ 2,416,000$ - a multiplication by almost 34 of the 1981-2 figures. In total, between 1981 to 1985, 494 projects were funded for a total sum $£ 5,222,854 .{ }^{52}$ "By deliberately setting out to fund art-forms and areas of London not hitherto in receipt of cash we believe we have started to restore the balance previously so grotesquely tipped towards the favoured few", noted chairman of the Community Arts Subcommittee George Nicholson when looking back on the achievements of the GLC in 1986 , with the abolition of the GLC only a few months ahead..$^{53}$

By giving support to popular, non-institutionalised art forms and to alternative structures of production based on collective and empowering practices, the Labour GLC harnessed community arts in the task of "inject[ing] radicalism into municipal politics". ${ }^{54}$ Those on the left desirous to modernise the Labour Party argued that such a project should fully engage with the arts, particularly with objectives of accessibility and participation in the production and enjoyment of culture. There were clear echoes of such calls at the national community arts conference organised in 1987 by the Shelton Trust:

We propose that Labour can draw one basic principle from the work which community artists have been engaged in. Labour should look to build a society in which people are free to come together to produce, distribute and receive cultures of their own choice, i.e. to create a cultural democracy. ${ }^{55}$

In 1986, the GLC and the Metropolitan County Councils were abolished. This was a pledge of the 1983 Conservative Manifesto, the Prime Minister invoking the need "to curb the extravagance of high-spending councils" ${ }^{56}$ Livingstone's administration fought the decision with significant communications means and resources from the Arts and Recreation Committee in the last year of its existence. ${ }^{57}$ With further cuts in public expenditure, combined with a marked ideological turn away from collective values 
towards individualism, the community arts movement eventually petered out. However, community arts practices survived into the 1990s in other ways, albeit depoliticised ones, under the less "radical" and more "remedial" term of "participatory arts"..$^{58}$ Community artists in the 1970 s had been guided by radical ideals of making art accessible for people to use it as tools for the expression of their needs, both collective and individual. By the late 1980s, the professionalization of the roles played by artists, and the demands placed on them by funders and stakeholders effectively contributed to disempowering community arts practices, reducing their radical efficiency and rendering unavailable the movement's history to newcomers in the field. ${ }^{59}$

\section{Conclusion}

Community arts in the United Kingdom was nurtured by the intellectual and radical counterculture of the late 1960s and the thrust to reconcile arts and politics, topple the cultural hierarchies defined by a bourgeois elite, and liberate art practices from established canons and forms. From dozens of alternative spaces across the country, community arts organisations campaigned for the right of every individual to exercise their own creativity and have access to participation in progressive, liberating and empowering actions that could take place in and through art. Such activities held revolutionary potential as they gathered people in campaigns were the line between artistic creativity and political activism dissolved. As the movement grew in the first half of the 1970s from the margins of the dominant art world, the path pursued was to make demands on the Arts Council of Great Britain to honour its duty to support access to the arts and artistic creativity. However, this pragmatic choice made the radical edge of these practices vulnerable to accommodation and recuperation in definitions given to them by their funders. This started a process of gathering the rebellious community arts movement into the fold of what was politically acceptable in mainstream art practices.

From 1979 and at a rapid pace in the following years, the new Conservative government radically transformed the post-war consensus on cultural policy, until then administered by a semi-autonomous Arts Council with expert appointees. The new personnel appointed by the government were both cultural conservatives and partisans of the new neoliberal orientations adopted by the Prime Minister in all spheres of government action. For the first time in its history, the Arts Council had to work on reduced budgets, discontinue funding to some of its clients, and accept the generalisation of private sponsorship in funding practices. The conservative values and conceptions of culture held by the Prime Minister designated community arts as an obvious target. Such practices, which embodied collective values, constituted a legacy of the 1960s counterculture that she was determined to eradicate and a vocal, even if marginal, space of resistance to her political vision.

The fact that the GLC, under the leadership of Ken Livingstone between 1981 and 1986, chose to embrace community arts as integral to a transformative project for the left, was a sign of the radical potential of these practices in the eyes of Labour modernisers. The Community Arts Sub-committee supported scores of organisations which kept alive the principles of collective, independent cultural production while serving "the making of a popular culture", for the people and by the people. The experience of the GLC meant that there was a moment in the 1980 s when community arts was a key 
participant in a cultural battle, when these practices thrived and were radicalised again in the campaign for cultural democracy.

When the GLC was abolished, perhaps as a sign of the oppositional power it constituted for the Government, these sources of support were lost. Local authorities across the country were hard put to continue funding cultural activities when rate-capping placed limits on their spending capacities. The ideological turn towards individualism, enterprise culture, and free markets was too powerful a current for community art to be able to survive in its more radical realisations. The process of depoliticisation of community arts as it morphed into "participatory art" can be viewed as a case study of the way cultural hegemony regenerates itself through the incorporation of dissent. The adaptation into mainstream cultural practice of principles such as participation in and access to the arts is a case in point. These terms have been co-opted and accepted as normal and expected practice in cultural institutions today. Yet the invocation of participation and access is largely framed in terms of education, personal development, creativity or entertainment, and not anymore as the pursuit of collective empowerment or community development.

\section{BIBLIOGRAPHY}

Another Standard, Culture and Democracy: The Manifesto, (London, Comedia and the Shelton Trust, 1986).

Arts Council of Great Britain, Community Arts. A Report of the Community Arts Working Party (London, Arts Council, 1974).

Arts Council of Great Britain, Community Arts - A report by the Arts Council's Community Arts Evaluation Working Group (London, Arts Council, 1977).

Atashroo, Hazel, "Beyond the 'Campaign for a Popular Culture', Community Art, Activism and Cultural Democracy in 1980s London”, (PhD Dissertation, University of Southampton, 2017).

Bertrand, Mathilde, "More than one finger on the shutter? Photography as Collaboration and the Legacies of Community Photography in Contemporary Practice", Photography For Whom \#2, Ed. Anthony Luvera, Coventry : Coventry University, 2021.

Bertrand, Mathilde, "The Half Moon Photography Workshop and Camerawork: catalysts in the British photographic landscape (1972-1985)", Photography and Culture, 11:3, 2018, 239-259, DOI: 10.1080/17514517.2018.1465649

Bertrand, Mathilde, « Les Community arts en Grande-Bretagne : un mouvement artistique engagé, 1968-1990 ", in John Mullen, Laurent Curelly (Eds) Forms of Activism in the United Kingdom (Grassroots Activism, Culture, Media), Revue Française de Civilisation Britannique, XXII-3 | 2017. DOI: https://doi.org/10.4000/rfcb.1523

Bertrand, Mathilde, “'Making the Art of Fun Freely Accessible': Community Arts Practices and the Politics of Leisure in Britain in the 1970s and 1980s", ANGLES/ French Perspectives on the Anglophone World, 2017. https://journals.openedition.org/angles/1225 
Boal, Augusto, Theatre of the Oppressed (London, Pluto, 1979).

Bianchini, Franco, “GLC R.I.P. Cultural Policies in London 1981-1986”, New Formations, $\mathrm{N}^{\circ} 1$ (Spring 1987), pp. 103-117.

Bishop, Claire, Artificial Hells. Participatory Arts and the Politics of Spectatorship (London and New York, Verso, 2012).

Conservative Party, Conservative Party General Election Manifesto, 1979.

Dickson, Malcolm (Ed.), Art with People, (Sunderland, AN Publications, 1995).

Doustaly, Cécile, « La décentralisation des politiques culturelles », Revue Française de Civilisation Britannique [Online], XIII-2 | 2005. https://doi.org/10.4000/rfcb.3426

Doustaly, Cécile, « Le soutien public à l'art en Angleterre du XIXe siècle à la fin des années 1960 : de la démocratisation de la culture à la démocratie culturelle?» Thèse. Dir : Jean-Claude Sargeant, Paris 3, 2007.

Doustaly, Cécile « Les Politiques de soutien à l'art en Angleterre depuis 1990 : « exception britannique ", dirigisme ou modèle hybride ? ", Revue LISA/LISA e-journal, Vol. V - n¹ | 2007, 6-32. Doustaly, Cécile, « Les politiques de démocratisation culturelle en Grande-Bretagne de 1940 à nos jours : légitimation ou instrumentalisation? », Territoires contemporains, Université de Bourgogne, 2013, http://tristan.u-bourgogne.fr/CGC/publications/Democratiser_culture/C_Doustaly.html.

Freire, Paolo, Pedagogy of the Oppressed (New York, Herder and Herder, 1970).

Greater London Council, The State of the Art or Art of the State? Strategies for the Cultural Industries in London (London, GLC, 1985).

Greater London Council, Campaign for a Popular Art. A Record of Struggle and Achievement: the GLC's Community Arts Programme 1981-1986 (London, GLC, 1986).

Gray, Clive, The Politics of the Arts in Britain. (London: Palgrave Macmillan, 2000).

Hall, Stuart, “The Great Moving Right Show”, Marxism Today, January 1979, pp. 14-20.

Hall, Stuart and Jefferson, Tony, Resistance Through Rituals; Youth Subcultures in Post-War Britain, (London, Routledge, 1993).

Harvest, Felicity and Merkel, Karen, "Community Arts and Cultural Democracy", January 1987, unpublished paper.

Hebdige, Dick, Subcultures. The Meaning of Style, (London, Methuen, 1979).

Hetherington, Janet and Webster, Mark, "From Handbooks to Live Labs: The Impact of Ideas from the 1970s and 1980s on the Training and Education of Community Artists Today", in Jeffers and Moriarty (ed.), Culture, Democracy and the Right to Make Art (London, Methuen, 2017), pp 183-202.

Hewison, Robert, Culture and Consensus: England, Arts and Politics Since 1940, (London: Routledge, 2015).

Higgins, Lee, Community Music: In Theory and In Practice (Oxford, Oxford University Press, 2012).

Hillman Chartrand, Harry ; McCaughey, Claire, "The Arm's Length Principle And The Arts: An International Perspective - Past, Present And Future", in Who's to Pay? for the Arts: The International Search for Models of Support, M.C. Cummings Jr \& J. Mark Davidson Schuster (eds.) American Council for the Arts, N.Y.C, 1989.

Jeffers, Alison ; Moriarty, Gerri ; Culture, Democracy and the Right to Make Art. The British Community Arts Movement. (London : Methuen, 2017). 
Kelly, Owen, Community, Art and the State: Storming the Citadels (London: Comedia, 1984).

Matarasso, François, "All in this Together: The Depoliticisation of Community Art in Britain in Britain, 1970-2011”, in Eugene Van Erven (ed.), Community Art Power. Essays from ICA 2011, (Rotterdam, Rotterdam Wikjtheater, 2013), pp. 214-239.

Matarasso, François, A Restless Art, (London: Calouste Gulbenkian Foundation, 2019).

Mortier, Janie, «L'âge d'or de l'Arts Council ou comment faire une politique culturelle sans le dire ", QWERTY, Vol. 8, Oct 1998.

Nigg, Heinz and Wade, Graham, Community Media, Community Communication in the United Kingdom : Video, Local TV, Film and Photography (Zurich, Regenbogen-Verlag, 1980).

Peacock, Keith, Thatcher's Theatre: British Theatre and Drama in the Eighties (Westport, Greenwood Press, 1999).

Philips, Deborah and Whannel, Garry, The Trojan Horse: The Growth of Commercial Sponsorship (New York, Bloomsbury, 2013).

Sinclair, Andrew, Arts and Cultures; The History of the Fifty Years of the Arts Council of Great-Britain (London, Sinclair-Stevenson, 1995).

Thatcher, Margaret, The Downing Street Years (London, Harper Press, 2011).

\section{NOTES}

1. See Owen, Kelly, Community, Art and the State: Storming the Citadels (London: Comedia, 1984); Alison Jeffers and Gerri Moriarty, Culture, Democracy and the Right to Make Art. The British Community Arts Movement. (London : Methuen, 2017).

2. See Cécile Doustaly, « Les politiques de démocratisation culturelle en Grande-Bretagne de 1940 à nos jours : légitimation ou instrumentalisation?", Territoires contemporains, Université de Bourgogne, 2013, http://tristan.u-bourgogne.fr/CGC/publications/Democratiser_culture/ C_Doustaly.html.

3. See Janie Mortier, «L'âge d'or de l'Arts Council ou comment faire une politique culturelle sans le dire ", QWERTY, Vol. 8, Oct 1998; Cécile Doustaly, "Le soutien public à l'art en Angleterre du XIXe siècle à la fin des années 1960 : de la démocratisation de la culture à la démocratie culturelle?» Thèse. Dir: Jean-Claude Sargeant, Paris 3, 2007; Cécile Doustaly, "La décentralisation des politiques culturelles", Revue Française de Civilisation Britannique [Online], XIII-2 | 2005.

4. See Mathilde Bertrand, « Les Community arts en Grande-Bretagne : un mouvement artistique engagé, 1968-1990", in John Mullen, Laurent Curelly (Eds) Forms of Activism in the United Kingdom (Grassroots Activism, Culture, Media), Revue Française de Civilisation Britannique, XXII-3 | 2017. DOI: https://doi.org/10.4000/rfcb.1523

5. Paolo Freire, Pedagogy of the Oppressed (New York, Herder and Herder, 1970); Augusto Boal, Theatre of the Oppressed (London, Pluto, 1979).

6. See Mathilde Bertrand, “'Making the Art of Fun Freely Accessible': Community Arts Practices and the Politics of Leisure in Britain in the 1970s and 1980s", ANGLES/ French Perspectives on the Anglophone World, 2017. https://journals.openedition.org/angles/1225

7. "underground, adj. and n." OED Online, Oxford University Press, June 2021, www.oed.com/ view/Entry/211700. Accessed 23 June 2021. 
8. See Stuart Hall and Tony Jefferson, Tony, Resistance Through Rituals; Youth Subcultures in PostWar Britain, (London, Routledge, 1993); Dick Hebdige Subcultures. The Meaning of Style, (London, Methuen, 1979).

9. Malcolm Dickson (Ed.), Art with People, (Sunderland, AN Publications, 1995), p. 16.

10. Drawing on an analysis of the movement from its early years, François Matarasso provides a rights-based definition of community arts : "Community art is the creation of art as a human right, by professional and non-professional artists, co-operating as equals, for purposes and to standards they set together, and whose processes, products and outcomes cannot be known in advance". A Restless Art. (London: Calouste Gulbenkian Foundation, 2019). p. 51.

11. Lee Higgins, Community Music: In Theory and In Practice (Oxford, Oxford University Press, 2012), p. 29.

12. The "New Activities Committee" (1969) was replaced by the "Experimental Projects Committee" (1970-73) to take into account artistic forms and practices such as Arts Labs, community arts but also performance art. In the same spirit, in 1973, the Arts Centres SubCommittee was also created, in order to encourage the creation of cultural centres in provincial towns which would "accommodate the local amateur as well as the visiting professional". "ACGB and Arts Centres", guide to the catalogue of the Arts Council of Great Britain Archives, https:// www.reading.ac.uk/ftt/research/ftt-givingvoice.aspx?\#ACGB Accessed March 2020.

13. Heinz Nigg and Graham Wade, Community Media, Community Communication in the United Kingdom: Video, Local TV, Film and Photography (Zurich, Regenbogen-Verlag, 1980), p. 30.

14. Owen Kelly, Op. Cit., p. 15.

15. Arts Council of Great Britain, Community Arts. A Report of the Community Arts Working Party (London, Arts Council, 1974), p. 9.

16. Ibid., p. 10.

17. Ibid.,p. 10. Another report in 1977 confirmed that community arts were "consistent with the Council's chartered duties". Arts Council of Great Britain, Community Arts - A report by the Arts Council's Community Arts Evaluation Working Group. (London: Arts Council, 1977).

18. In 1972, out of a budget of $£ 9,3$ million, the Arts Council financed fifty-seven community arts organisations for a total of $£ 176,000$ ( $1,8 \%$ of its budget). The next year, $£ 350,000$ were attributed to seventy-five projects. (Heinz Nigg and Graham Wade, Op. Cit., p.30; Kelly, Op. Cit., p.15). By 1978, grants given to community arts reached a million pounds, see Andrew Sinclair, Arts and Cultures; The History of the Fifty Years of the Arts Council of Great-Britain (London, Sinclair-Stevenson, 1995), pp.184-5, p.224. This still represented insufficient funding spread out among numerous organisations and constituted only a fraction of the Council's overall budget of about 52,3 million for the year 1978-79 (1,91\%). See Clive Gray, The Politics of the Arts in Britain, (London: Palgrave Macmillan, 2000), p. 49.

19. Felicity Harvest and Karen Merkel, "Community Arts and Cultural Democracy", (unpublished paper, January 1987), p. 1.

20. Private foundations such as the Calouste Gulbenkian Foundation - UK Branch were regular supporters of projects. Other government schemes provided support such as the Urban Renewal programme or the Manpower services. It is also important to underline that many community artists lived on unemployment benefits and some chose or resorted to squatting.

21. Owen Kelly, Op. Cit., p.15; Heinz Nigg and Graham Wade, Op. Cit. p. 9.

22. Cécile Doustaly, «Les Politiques de soutien à l'art en Angleterre depuis 1990 : «exception britannique ", dirigisme ou modèle hybride?", Revue LISA/LISA e-journal, Vol. V - n¹|2007, p. 6-32.

23. Thus echoing Lord Melbourne: "God help the minister that meddles with art!". Quoted by Harry Hillman Chartrand \& Claire McCaughey, "The Arm's Length Principle And The Arts: An International Perspective - Past, Present And Future", in Who's to Pay? for the Arts: The International 
Search for Models of Support, M.C. Cummings Jr \& J. Mark Davidson Schuster (eds.) American Council for the Arts, N.Y.C, 1989.

24. Thatcher, Margaret, The Downing Street Years (London, Harper Press, 2011), p. 632.

25. Quoted in Andrew Sinclair, Op. Cit., p. 248.

26. Business sponsorship had the added advantage of allowing companies to project a positive brand image. See Philips Deborah and Garry Whannel, The Trojan Horse: The Growth of Commercial Sponsorship (New York, Bloomsbury, 2013), p. 99.

27. Philips Deborah and Garry Whannel, Op. Cit., p. 103.

28. Robert Hewison, Culture and Consensus: England, Arts and Politics Since 1940, (London: Routledge, 2015), p. 229.

29. Ibid., p. 246.

30. Ibid. p. 246, and Keith Peacock, Thatcher's Theatre: British Theatre and Drama in the Eighties (Westport, Greenwood Press, 1999), p. 36.

31. Robert Hewison, Op. Cit., p. 152.

32. Claire Bishop, Artificial Hells. Participatory Arts and the Politics of Spectatorship (London and New York, Verso, 2012), p. 187.

33. The concept of cultural democracy had been discussed through the 1970s within the movement, but Owen Kelly was the first community artist to write consistently about it in 1984 and propose that it become a core objective for the movement. See Owen Kelly, Op.Cit., p. 97.

34. François Matarasso, Op. Cit., Chapter 9, "Community Art and the Cultural Revolution (1968-1988).

35. Another Standard, Culture and Democracy: The Manifesto, (London, Comedia and the Shelton Trust, 1986), p. 10.

36. Ibid, p. 40.

37. Margaret Thatcher, Op. Cit. p. 2011.

38. Robert Hewison, Op. Cit. p. 212.

39. Stuart Hall, “The Great Moving Right Show”, Marxism Today, January 1979, p. 14-20.

40. In Manchester, Merseyside, South Yorkshire, Tyneside, the West Midlands and West Yorkshire.

41. Robert Hewison, Op. Cit. p. 237.

42. See Hazel Atashroo, "Beyond the 'Campaign for a Popular Culture', Community Art, Activism and Cultural Democracy in 1980s London”, (PhD Dissertation, University of Southampton, 2017), p. 45; Greater London Council, Campaign for a Popular Art. A Record of Struggle and Achievement: the GLC's Community Arts Programme 1981-1986 (London, GLC, 1986).

43. Hazel Atashroo, Op. Cit., p. 18.

44. Greater London Council, Op. Cit., Campaign for a Popular Culture, p. 17.

45. Ibid. p. 19.

46. Greater London Council, The State of the Art or Art of the State? Strategies for the Cultural Industries in London (London, Greater London Council, 1985), p. 6.

47. Franco Bianchini, "GLC R.I.P. Cultural Policies in London 1981-1986", New Formations, №1 (Spring 1987), p.107. Emphasis by the author. See also: "[The GLC's Community arts subcommittee] wanted to fund activities which not only benefitted that long list of people who are discriminated against in our society - the working class, women, black people, people with disabilities, Irish people, gays, lesbians, the elderly, the unemployed, young people - but which also linked with cultural campaigns fighting to overcome the reasons for their oppression." Greater London Council, Op. Cit. Campaign for a Popular Culture, p. 17.

48. Robert Hewison, Op. Cit. p. 238.

49. The See Red Women's Workshop's archive is accessible online. https:// seeredwomensworkshop.wordpress.com/ Accessed $24^{\text {th }}$ June 2021. 
50. See Mathilde Bertrand, "More than one finger on the shutter? Photography as Collaboration and the Legacies of Community Photography in Contemporary Practice", Photography For Whom \#2, Ed. Anthony Luvera, Coventry: Coventry University, 2021; "The Half Moon Photography Workshop and Camerawork: catalysts in the British photographic landscape (1972-1985)", Photography and Culture, 11:3, 239-259, DOI: 10.1080/17514517.2018.1465649

51. Greater London Council, Op. Cit. Campaign for a Popular Culture, p. 39.

52. Ibid., p. 38.

53. Ibid., p. 3.

54. Ibid., p. 2.

55. Felicity Harvest and Karen Merkel, "Community Arts and Cultural Democracy”, (unpublished paper, January 1987), p. 1.

56. Margaret Thatcher, Op. Cit., p.284.

57. Margaret Thatcher recognised that "the left-wing municipal socialists and their subsidized front organisations were astute campaigners, trained and adept at exploiting every weakness of presentation of the Government's case". Margaret Thatcher, Ibid., p.305. The GLC fought the case for abolition every inch of the way.

58. François Matarasso,"All in this Together: The Depoliticisation of Community Art in Britain in Britain, 1970-2011”, in Eugene Van Erven (ed.), Community Art Power. Essays from ICA 2011, (Rotterdam, Rotterdam Wikjtheater, 2013), p.216. Matarasso adds p.225 that the semantic change also reflected ideological evolutions: "[by 1988], politically at least, the idea of community was becoming rapidly discredited by an ascendant neoliberal ideology. The word was treated with suspicion by academics and radicals alike; it seemed increasingly tainted, particularly as Government co-opted its positive associations to rebrand policies such as the "community charge', 'community policing', and 'care in the community'."

59. Hetherington, Janet and Webster, Mark, "From Handbooks to Live Labs: The Impact of Ideas from the 1970s and 1980s on the Training and Education of Community Artists Today", in Jeffers and Moriarty (ed.), Culture, Democracy and the Right to Make Art (London, Methuen, 2017), p.192; François Matarasso, Op. Cit., p. 216-7.

\section{ABSTRACTS}

The emergence and development of the community arts movement in the UK from the late 1960s was premised on a critique of dominant cultural production and radical objectives of social, cultural and political change. Inspired by ground-breaking work in popular education and theatre (Freire, Boal) and nurtured by the counterculture of the 1960s, community artists defended the idea that artists had a political role to play in contexts outside of the studio or the art gallery. The projects they set up opened artistic practices to working class audiences and defended values of pluralism, accessibility and participation as the founding blocks of a renewed social art. The community arts movement occupied an oppositional position in relation to the cultural Establishment and attempted to challenge the elitism of the Arts Council. However, constantly maintained on a diet of limited and insufficient funding, and lacking support within the traditional labour movement, community arts organisations were never able to represent a solid radical alternative in the 1970s. From 1979, Margaret Thatcher's Conservative Government opposed the principle of State-sponsored cultural production. It based its cultural policy on 
objectives of reduced public expenditure, the growth of private sponsorship, and stronger control of the Arts Council's operations. In this specific juncture, the Greater London Council led by Labour Ken Livingstone (1981-1986) attempted to prove that there was an alternative, within a renewed radical socialism. His cultural policy for London gave pride of place to community arts practices and championed the objectives of cultural democracy, as defined in the spheres of the New Left and defended by the more radical fringe of the community arts movement around this period. The trajectory of community arts practices in the UK thus sheds lights on the cultural battles played out in the 1980s over concepts of cultural production, hegemony, popular culture and community activism. It also highlights how the radical contestation of cultural domination can be vulnerable to appropriation and depoliticisation in mainstream culture.

L'émergence et le développement du mouvement community arts à partir de la fin des années 1960 au Royaume-Uni se fonde sur une critique des modes de production culturelle dominants et se donne pour horizon des objectifs de changement social, culturel et politique. Inspirés par des travaux novateurs en matière d'éducation populaire et de théâtre (Freire, Boal) et nourris de la contre-culture des années 1960, les community artists défendent l'idée que l'art et les artistes ont un rôle politique à jouer, dans des contextes sociaux hors du studio ou de la galerie d'art. Les projets qu'ils initient ouvrent les pratiques artistiques à des publics populaires et défendent des valeurs de pluralisme, d'accessibilité et de participation comme fondement d'un art social renouvelé. Le mouvement community arts conteste la domination d'un Establishment culturel et remet en question l'élitisme de l'Arts Council. Cependant, maintenues précairement par des financements limités et toujours insuffisants, et en l'absence du soutien des forces de gauche traditionnelles, les organisations community arts ne parviennent pas à s'imposer comme une proposition alternative radicale dans les années 1970s. A partir de 1979, le gouvernement conservateur de Margaret Thatcher s'attaque au principe d'un soutien de l'Etat à la production artistique. Il fonde sa politique culturelle sur les objectifs de réduction des dépenses publiques, de généralisation des financements privés et d'un contrôle plus serré des opérations de l'Arts Council. C'est dans ce contexte que le Greater London Council, dirigé par le travailliste Ken Livingstone (1981-1986) s'emploie à prouver qu'une alternative est possible, dans le projet de refonte d'un socialisme radical. Sa politique culturelle pour Londres accorde une place de choix aux pratiques community arts et défend les objectifs de démocratie culturelle, notion apparues dans les milieux de la New Left et revendiqué par la frange plus radicale du mouvement community arts au cours de cette période. La trajectoire des pratiques community arts au Royaume-Uni permet de rendre compte des batailles culturelles qui se jouent dans les années quatre-vingt autour des concepts de production culturelle, d'hégémonie, de culture populaire et d'activisme communautaire. Elle met en lumière la structuration des contestations aux dominations culturelles mais aussi leur vulnérabilité face à leur appropriation et dépolitisation dans la culture mainstream.

\section{INDEX}

Keywords: community arts, mainstream, Greater London Council, Margaret Thatcher, Ken Livingstone, counterculture, cultural hegemony

Mots-clés: community arts, mainstream, Greater London Council, Margaret Thatcher, Ken Livingstone, contre-culture, hégémonie culturelle 


\section{AUTHOR}

\section{MATHILDE BERTRAND}

Université Bordeaux-Montaigne, CLIMAS, EA 4196

Mathilde Bertrand (Université Bordeaux-Montaigne, CLIMAS, EA 4196) est Maîtresse de Conférences en Civilisation Britannique. Ses recherches portent sur l'histoire de la photographie britannique et du mouvement community arts, et plus largement la culture visuelle dans le contexte des mobilisations politiques et sociales de la seconde moitié du XX $\mathrm{XX}^{\mathrm{e}}$ siècle. 